A N N A L E S

UNIVERSITATIS MARIAE CURIE-SKŁODOWSKA

LUBLIN - POLONIA

VOL. LXVI, 1

SECTIO G

2019

RYSZARD MAŁAJNY

\title{
Geneza konstytucji
}

The Origins of a Constitution

\section{WPROWADZENIE}

Pierwsze konstytucje zaczęto uchwalać pod koniec XVIII w., jednak ich pierwowzory pojawiły się półtora stulecia wcześniej. Na dobrą sprawę także w dalszej przeszłości możemy wskazać na istotne akty o charakterze ustrojowym. Tak np. w niektórych greckich poleis już w V w. p.n.e. istniały dokumenty kładące podwaliny ich ustroju. Znano też pojęcie zasad regulujących porządek demokratyczny (eunomia) oraz dotyczących równości (izonomia). Z czasów średniowiecza warto przypomnieć hiszpańską Kartę Królestwa Leon (1188), angielską Magnam Chartam Libertatum (1215) i węgierską Złotą Bullę (1222). Okres Renesansu to przede wszystkim polska „konstytucja” Nihil novi (1505), Artykuły henrykowskie (1573) i towarzyszące im pacta conventa. W Szwecji zaś ustanowiono Regeringsformen (1663). Z kolei w siedemnastowiecznej Anglii warto wymienić lewellerowską Umowę Ludu (Agreement of the People) z 1648 r. oraz cromwellowski Instrument rządzenia (Instrument of Government) z 1653 r. Ten ostatni Carl Joachim Friedrich uznał za pierwszą nowoczesną konstytucję. W dokumencie tym założono bowiem, że w każdym ustroju muszą istnieć jakieś nienaruszalne reguły zdolne przeciwstawić się woli zmiennych większości w Parlamencie.

Wymienione wyżej akty poręczały prawa stanów, normowały kwestię następstwa tronu, zawierały gwarancje niektórych wolności lub praw poddanych

1 Bodaj pierwszym autorem, który przedstawił projekt konstytucji, i to jeszcze z komentarzem, był James Harrington (The Commonwealth of Oceana z 1656 r.). Toteż Alois Riklin („Jahrbuch des öffentlichen Rechts der Gegenwart” 2000, Bd. 48, s. 14) nazwał go „prorokiem konstytucji pisanej”. 
bądź dążyły do usprawnienia funkcjonowania państwa. Postulat spisania podstawowych praw ustrojowych narodził się w purytańskiej rewolucji w opozycji wobec nieograniczonej władzy „Długiego Parlamentu” (Karl Loewenstein). W XVII stuleciu idea konstytucji wisiała w powietrzu, jako że daje się zauważyć ewolucję tego pojęcia w kierunku pojmowania go jako ustanowienia całościowego systemu władzy państwowej. Niemniej nie były to jeszcze ustawy zasadnicze².

Do początku XVIII w. dokumenty ustrojowe były opracowywane z punktu widzenia ochrony praw władcy, a nie ochrony praw jednostki. Dopiero te akty, które powstały z myślą o tej ostatniej, można nazwać konstytucją, z konstytucją USA na czele ${ }^{3}$.

Za pierwowzór ustawy zasadniczej można uznać karty konstytucyjne kolonii brytyjskich zachodniej hemisfery, które w 1776 r. ogłosiły niepodległość jako Stany Zjednoczone Ameryki. Władze angielskie, a później brytyjskie, w latach 1607-1732 zorganizowały na tych terytoriach 13 kolonii. Celem zintensyfikowania w nich akcji osadniczej nadano lub zatwierdzono każdej z nich kartę konstytucyjną (constitutional charter). Nie dochodziły więc one do skutku w drodze zwyczaju. Karty te, oprócz reglamentacji podstaw ustrojowych kolonii, zawierały też stosunkowo szeroki katalog wolności i praw jednostki. Warto tu wskazać przede wszystkim na Ugodę z Mayflower (Mayflower Compact) z 1620 r., Kartę Massachussetts ${ }^{4}$ z 1628 r., Księgę Praw (Book of Laws) przyjętą w Plymouth w 1636 r. ${ }^{5}$ oraz Fundamentalne Zarządzenia (Fundamental Orders) Connecticut z 1639 r. Te ostatnie - wzorowane notabene na Karcie Massachussetts - James Bryce nazwał „najstarszą prawdziwie polityczną konstytucją w Ameryce”. Charles Borgeaud określił je mianem , pierwszej amerykańskiej konstytucji przy-

2 Najkrótszy akt ustrojowy w dziejach to „Jedyny Artykuł” (Article unique) z 10 lipca 1940 r., stanowiący podstawę ustroju tzw. Państwa Vichy: „Zgromadzenie Narodowe przekazuje całą władzę Rządowi Republiki, działającemu pod kierownictwem marszałka Petaina, w celu ogłoszenia za pomocą jednego lub kilku aktów nowej Konstytucji Państwa Francuskiego. Konstytucja ta winna gwarantować prawa pracy, rodziny i ojczyzny. Zostanie ona ratyfikowana przez naród i wprowadzona w życie przez to Zgromadzenie, które powoła do życia".

3 K. Stern, Grundideen europäisch-amerikanischer Verfassungsstaatlichkeit, Berlin-New York 1984, s. 14-15.

4 Charles H. McIlwain (Constitutionalism Ancient and Modern, New York 1947, s. 241) uważał, że dokument ten nie był konstytucją w sensie ścisłym, niemniej w praktycznym użyciu był do konstytucji zbliżony.

5 Zdaniem George'a L. Haskinsa można uznać Księgę za pierwszą amerykańską konstytucję. Normowała bowiem podstawy aparatu państwowego kolonii, źródło władzy prawodawczej, obowiązki i kompetencje niektórych funkcjonariuszy kolonii, wymogi prawa wyborczego, kwalifikacje wymagane do objęcia urzędu sędziego, źródło kompetencji ogłaszania wojny. Zawierała też kartę praw. Instytucje te zostały upowszechnione w późniejszych dokumentach konstytucyjnych Ameryki Północnej. Zob. G.L. Haskins, The Legal Heritage of Plymouth Colony, [w:] American Law and the Constitutional Order. Historical Perspectives, eds. L.M. Friedman, H.N. Schreiber, CambridgeLondon 1978, s. 39. 
jętej przez lud” i ,pierwszej pisanej konstytucji nowoczesnej demokracji”. Z kolei William C. Morey orzekł, iż na pewno była to pierwsza ustawa zasadnicza uchwalona przez niezależny lud ${ }^{6}$. Są to opinie badaczy piszących u schyłku XIX w.

Ustrój kolonii był w przybliżeniu miniaturą ustroju metropolii. Zakładał on funkcjonalne i organizacyjne wyodrębnienie władzy wykonawczej, prawodawczej i sądowniczej, dwuizbowość legislatury oraz system hamulców. Stał się on wzorem dla uchwalanych później konstytucji stanowych (1776-1784), w tym dla obowiązującej do dziś ustawy zasadniczej stanu Massachussetts z 1780 r. Zwieńczeniem tego procesu stało się uchwalenie konstytucji USA w dniu 17 września 1787 r., która weszła w życie 4 marca 1789 r.

\section{TŁO SPOŁECZNO-EKONOMICZNE}

Nie jest przypadkiem, że konstytucja Stanów Zjednoczonych została uchwalona 11 lat po wybuchu rewolucji amerykańskiej, a pierwsza ustawa zasadnicza Francji - 2 lata po wybuchu rewolucji francuskiej. To samo można rzec o konstytucjach państw niemieckich i włoskich z czasów Wiosny Ludów, z konstytucją Prus z 1850 r. na czele. Później zaś powiemy tak o ustawach konstytucyjnych Rosji (stanowiących pokłosie rewolucji 1905 r.), konstytucjach państw „demokracji ludowej" po 1945 r. i w końcu o ustawach konstytucyjnych uchwalonych po Jesieni Ludów z 1989 r. Każda rewolucja siłą rzeczy gruntownie zmienia istniejący porządek ustrojowy, który znajduje potem swój wyraz prawny w ustawie zasadniczej. Żaden inny akt normatywny nie daje bowiem takiej gwarancji nieodwracalności rewolucyjnych zmian, jak właśnie ten.

Osiemnastowieczni publicyści francuscy doszli do wniosku, iż konstytucja musi mieć formę ustawy. Uznali oni bezapelacyjną wyższość prawa pisanego nad zwyczajem, a tym bardziej jego najważniejszych reguł - konstytucyjnych. Upatrywali więc $\mathrm{w}$ konstytucji, uchwalonej przez sprawujący swe zwierzchnictwo naród, prawdziwego odnowienia umowy społecznej. Jej punkty należało wyrazić w formie jak najbardziej uroczystej i jak najpełniejszej. Dopiero tak zredagowana konstytucja może być najlepszym środkiem politycznego wychowania ${ }^{7}$.

Rewolucje schyłku XVIII w. i późniejsze pociągnęły za sobą rozwój kapitalizmu. Nowe stosunki produkcji wymagały zniesienia przywilejów i więzów feudalnych, a zwłaszcza poddaństwa chłopów, którzy byli potrzebni w miastach wskutek wyczerpania się tamtejszej siły roboczej. To zaś wymagało nadania odpowiednio wysokiej rangi prawnej zasadzie równości jednostek wobec prawa - jednostek rozumianych jako obywatele. To samo dotyczyło prawa własności,

6 W.C. Morey, The Genesis of a Written Constitution, "Annals of the American Academy of Political and Social Science" 1891, No. 4, s. 551, 556; C.H. McIlwain, op. cit., s. 241.

A. Esmein, Prawo konstytucyjne, Warszawa 1921, s. 444. 
czego oczekiwała zwłaszcza burżuazja. Wojny napoleońskie przyczyniły się do akceptacji tych idei w Europie w pierwszych dwóch dziesięcioleciach XIX stulecia. Podobnie Wiosna Ludów z 1848 r. doprowadziła do przekształcenia się niektórych monarchii absolutnych w monarchie konstytucyjne. Konstytucja miała więc petryfikować osiągnięty w wyniku rewolucji postęp społeczny.

W każdym razie do Wiosny Ludów burżuazja niemiecka domagała się konstytucji pisanej (lex scripta), czyli nie dowolnej, lecz zawierającej określone żądania. W ten sposób doszło do pojawienia się konstytucji w sensie formalnym. Przyjęto bowiem założenie, że to, co utrwalone w formie pisemnej, można łatwiej udowodnić, a ponadto dzięki temu treść konstytucji będzie bardziej trwała; ponadto konstytucja powinna zostać wydana przez właściwy organ i we właściwej procedurze ${ }^{8}$.

\section{TŁO IDEOLOGICZNE}

Schyłek XVIII w. to czas, w którym dominującymi prądami umysłowymi były racjonalizm i liberalizm. Pierwszy z nich uznawał rozum człowieka za najważniejsze źródło poznania rzeczywistości i kryterium prawdziwości ocen. Toteż pisarze oświeceniowi uważali, że dotychczasowe instytucje ustrojowe, które nie sprostały racjonalistycznej analizie, powinny zostać zastąpione nowymi. Winny one zyskać walor powszechny, a ich zakotwiczeniem powinna stać się konstytucja jako najwyższy świecki akt normatywny państwa. Miał to być „czarodziejski pergamin” (Hans Vorländer) albo swoista „biblia narodu”, która jest „tym dla wolności, czym gramatyka dla języka" (Thomas Paine). W organizacji społeczeństwa można wymyślić nowe formy, zapisać je w konstytucji i stosować. Rozumne reguły rządzenia potrzebne są po to, aby „stojąc zawsze przed oczyma wszystkich członków społeczeństwa, przypominały im nieustannie ich prawa i obowiązki" ". Przypomina się tu popularna sentencja Immanuela Kanta, iż „problem zorganizowania państwa jest rozwiązywalny, mówiąc bez ogródek, nawet dla narodu diabłów (jeśli tylko posiadają one rozum)" ${ }^{\text {"10 }}$. Dlatego wysunął on postulat uchwalenia konstytucji ${ }^{11}$.

Zresztą niektórzy autorzy utrzymują, iż rozwój konstytucji rozpoczął się wraz z Reformacją. Jednym z jej postulatów była religijna delegitymizacja władzy państwowej, która osłabiła nie tylko potestatem papieża, ale i władców świeckich. Władcy zrekompensowali to sobie poprzez sekularyzację i pozytywizację prawa. Ta ostatnia oznaczała, że prawo może być każdorazowo zmieniane, a więc

8 C. Schmitt, Nauka o konstytucji, Warszawa 2013 (1928), s. 42.

Wstęp do Deklaracji Praw Człowieka i Obywatela.

10 I. Kant, Projekt wieczystego pokoju, Warszawa 1995, s. 120.

11 Zob. Metaphysik der Sitten oraz Metaphysische Anfangsgründe der Rechtslehre. 
zinstrumentalizowane - jakkolwiek generalnie winno być sztywne. Odróżniało to konstytucję od polityki i zastępowało nią religijną legitymację władzy ${ }^{12}$.

Liberalizm z kolei akcentował wolność i równość wszystkich ludzi - niezależnie od ich przynależności stanowej - także w dziedzinie działalności gospodarczej. W amerykańskiej Deklaracji Niepodległości z 4 lipca 1776 r. czytamy m.in.:

Uważamy następujące prawdy za oczywiste: że wszyscy ludzie zostali stworzeni równi, że Stwórca obdarzył ich pewnymi nienaruszalnymi prawami, że w skład tych praw wchodzi życie, wolność i swoboda dążenia do szczęścia, że celem zapewnienia tych praw wyłonione zostały wśród ludzi rządy, których sprawiedliwa władza wywodzi się ze zgody rządzonych [...].

Analogicznie francuska Deklaracja Praw Człowieka i Obywatela w art. I stwierdzała: „Ludzie rodzą się oraz pozostają wolni i równi wobec prawa. Podstawą różnic społecznych może być wyłącznie wzgląd na korzyści społeczne". Oba te nurty ideowe odegrały ważną rolę $\mathrm{w}$ walce $\mathrm{z}$ ancien régime'em. Konstytucja była więc także dokumentem propagandowym, wyrażającym program burżuazji w dziedzinie instytucji społecznych. Miała być ewangelią sprawiedliwego ładu ustrojowego oraz przemawiać do umysłów poszczególnych osób, skłaniając ich do uznania zawartych tam prawd i ich realizacji.

Niemniej w kontekście genezy konstytucji tworzyły one jedynie tło ideologiczne. Rolę pierwszorzędną odegrały bowiem takie idee, jak: praw naturalnych, suwerenności ludu, umowy społecznej, podziału władzy i pozytywizmu prawniczego.

Idea praw naturalnych głosiła, że każdy człowiek, przychodząc na świat, przynosi niejako $\mathrm{w}$ wianie pewne niezbywalne prawa, których państwo nie może nadać. Co do katalogu tych praw pojawiły się różnice poglądów, niemniej wszyscy zgadzali się, iż obejmują one prawo do życia, wolności i własności. Prawa te siłą rzeczy ograniczają władzę państwową, a ich naruszenie usprawiedliwia wystąpienie przeciwko niej. Jest więc pożądane, żeby je spozytywizować w jednym uroczystym akcie. Nie wszyscy wszak podzielali ten pogląd, jako że niektórzy obawiali się, iż taki krok mógłby zdeprecjonować ich rangę (m.in. amerykańscy Founding Fathers). Stopniowo jednak przewagę zyskało przekonanie, że wolności i prawa jednostki stanowią integralny element ustawy zasadniczej. Jego odzwierciedlenie zawiera chociażby Deklaracja Praw Wirginii z 1776 r., która w $§ 1$ stanowiła, że „Wszyscy ludzie są z natury w równym stopniu wolni i niezależni oraz posiadają pewne przyrodzone prawa, których gdy wstępują w stan społeczny, na mocy żadnej umowy nie mogą pozbawić swoich potomków"13. Idee te wystę-

12 G. Roellecke, Institutionelle Gewähr der Verfassung, [w:] Verfassungstheorie, Hrsg. O. Depenheuer, C. Grabenwarter, Tübingen 2010, s. 502.

13 Umowa społeczna jako podstawa aksjologiczna znalazła swój refleks nie tylko w pierwszych, ale i w kolejnych konstytucjach stanowych w USA. I tak explicite wyrażała ją ustawa zasadnicza Ken- 
pują też m.in. w Deklaracji Niepodległości, Bill of Rights z 1789 r. i francuskiej ustawie zasadniczej z $1791 \mathrm{r}$.

Idea suwerenności ludu zakłada, że to on jest podmiotem władzy najwyższej. Przysługuje mu zatem pełne prawo do nadania sobie konstytucji jako najwyższego aktu prawnego, który będzie legitymizować jego władzę. Temu przeświadczeniu hołduje m.in. Deklaracja Niepodległości, w której czytamy, iż „,prawem narodu jest zmienić formę rządu albo obalić i utworzyć nowy". W analogicznej tonacji utrzymany jest art. III Deklaracji Praw Człowieka i Obywatela: „Początek wszelkiej władzy należy z istoty swej do narodu; żadne ciało, żadna jednostka nie może sprawować władzy, która nie pochodzi od narodu”. Władza ta winna więc zostać skodyfikowana w jednym akcie o najwyższej randze.

Idea umowy społecznej wiązała się z ideologią praw naturalnych. Zgodnie $\mathrm{z}$ tą pierwszą ludzie po to stworzyli państwo, by chroniło ich życie, prawa i mienie. Posiada więc ono władzę delegowaną, którą społeczeństwo przekazało monarsze (Grocjusz, John Locke, Samuel von Pufendorf). Z kolei zdaniem Jana Jakuba Rousseau ludzie zawarli taką umowę między sobą (wola powszechna). Wcześniej amerykańscy purytanie, w ślad za Kalwinem, upatrywali podstawy organizacji Kościoła w umowie między członkami kongregacji, które to przekonanie dało później początek poglądowi, że również państwo powinno dojść do skutku w drodze umowy między obywatelami. Konstytucja stanowiła pisemną formę tej umowy. Takie przekonania legły u podstaw jednego z prototypów konstytucji, jakim była w Anglii lewellerowska The Agreement of the People oraz północnoamerykańskie karty konstytucyjne. Jeśli krytykuje się panujący ustrój polityczny jako nieodpowiadający warunkom kontraktu społecznego (stanowiącego podstawę istnienia państwa), to gruntowna reforma polityczna traktowana jest jako odnowienie umowy społecznej, co winno nastąpić w akcie pisemnym $\mathrm{i}$ jest równoznaczne $\mathrm{z}$ ustanowieniem $\mathrm{w}$ państwie konstytucji ${ }^{14}$.

$\mathrm{Z}$ historycznego punktu widzenia ustawy zasadnicze są produktem sporu między liberalną burżuazją a monarchami absolutnymi. Burżuazji chodziło o wyemancypowanie sfery produkcji i dziedziczenia od „zwierzchności” i nieobliczalności władzy państwowej. Dlatego żądała ona ograniczenia monarszych kompetencji do spraw bezpieczeństwa i porządku publicznego, jak również uczestniczenia w kształtowaniu woli państwa w kwestiach dotyczących wolności i własności. Żądania te uzasadniano argumentami prawnonaturalnymi, domagając się ich zabezpieczenia w postaci konstytucji. Akt ten powinien obejmować m.in. uregulowanie sytuacji prawnej legislatywy jako ciała reprezentującego burżuazję

tucky (1792), Mississippi (1817), Alabamy (1819), Arkansas (1836), Florydy (1838), Texasu (1845), Oregonu (1857). Natomiast implicite zawierało ją około 10 innych konstytucji. Zob. K. Maćkowska, Normatywny wymiar amerykańskich wczesnych konstytucji stanowych, Lublin 2008, s. 64.

14 Zob. M. Loughlin, What is Constitutionalisation?, [w:] The Paradox of Constitutionalism. Constituent Power and Constitutional Form, eds. M. Loughlin, N. Walker, Oxford 2007, s. 50. 
i pośredniczącego w zaspokajaniu jej potrzeb wobec państwa, zasadę wyłączności ustawy oraz niezawisłości sądów ${ }^{15}$.

Naturalnie konstelacji, z której zrodziły się te konstytucje, już nie ma. W państwie demokratycznym ustawy zasadnicze straciły swój charakter umowy społecznej i stały się rodzajem samoorganizacji społeczeństwa. Rewolucja przemysłowa stworzyła problemy społeczne, o których dokumenty te nie wspominały. W strefie uwolnionej od władzy monarszej pojawiły się bowiem nowe centra władzy i mechanizmy ucisku. Sfera wolności jednostki uległa takiemu zwężeniu, że ona sama nie może zagwarantować swego istnienia. Wolna gra sił społeczno-politycznych jeszcze nie gwarantuje sprawiedliwości ${ }^{16}$.

W Europie pierwsze ustawy zasadnicze miały być wyrazem ograniczenia władzy monarszej. Określenie reguł organizacji i funkcjonowania aparatu państwa miało uniemożliwić powrót do absolutyzmu. Od samego początku przypisywano więc konstytucji nie tylko walor organizacyjny, lecz także gwarancyjny. Jak orzekł Klaus Stern, do początku XVIII w. akty ustrojowe były opracowywane głównie z punktu widzenia władcy, a ściślej - ochrony jego praw, a nie praw jednostki. Dopiero te akty, które powstały z myślą o tej ostatniej, można nazwać konstytucjami ${ }^{17}$. Punktem zwrotnym w pogodzeniu monarchii z ideami konstytucjonalizmu stała się ustawa zasadnicza Belgii z 1831 r. Jej twórcom udało się rozwiązać kwadraturę koła pomiędzy królewskimi prerogatywami a zasadą suwerenności narodu poprzez przyjęcie formuły, iż cała władza od niego pochodzi (art. 25) ${ }^{18}$.

Tam, gdzie w ustawie zasadniczej proklamowano zasadę suwerenności narodu, wszystkie organy państwa mogły wykonywać tylko takie kompetencje, które konstytucja lub akty na jej podstawie wydane wyraźnie im przyznawały. Odnosiło się to także do monarchy, uważanego za organ władzy wykonawczej (np. Konstytucja 3 Maja). Tam zaś, gdzie obowiązywała „zasada monarchiczna”, monarsze - jako źródłu suwerenności nadającemu konstytucję - przysługiwały nie tylko kompetencje wymienione w ustawie zasadniczej, lecz także te, których ona nie zastrzegła dla innych organów państwa ${ }^{19}$.

15 D. Grimm, Verfassungsfunktion und Grundgesetzreform, „Archiv des öffentlichen Rechts“ 1972, Bd. 97(4), s. 491-492.

16 Ibidem, s. 492.

17 K. Stern, Grundideen..., s. 14-15.

18 K. Loewenstein, Verfassungslehre, Tübingen 1969 (1957), s. 138. Według Martina Kirscha konstytucje dawniejsze można podzielić na te, które ustanawiały przewagę monarchy, oraz na te, które wprowadzały supremację parlamentu. Do tych pierwszych należały ustawy zasadnicze Francji z lat 1814-1830 oraz większości państw niemieckich, zwłaszcza Prus (1850) i Rzeszy (1871). Do tych drugich natomiast - konstytucje Francji z lat 1791 i 1830-1848, Belgii (1831), Piemontu (1852), Włoch (1860) i Badenii (1860-1865). Zob. R. Wahl, Der Konstitutionalismus als Bewegungsgeschichte, „Der Staat“ 2005, Nr. 4, s. 577.

19 H. Izdebski, Konstytucja Trzeciego Maja wśród konstytucji swojego wieku, „Państwo i Prawo" 1991 , z. 5, s. 12. 
Konstytucje ówczesne można podzielić na oktrojowane i uchwalone przez parlament. Najbardziej znane spośród tych pierwszych to francuska Charte Constitutionelle z 1814 r. i konstytucja lipcowa z 1830 r. oraz konstytucje bawarska i wirtemberska. W 1848 r. król Karol Albert nadał Państwu Sardyńskiemu Kartę Konstytucyjną jako „wieczystą i nieodwołalną ustawę zasadniczą monarchii”. Nazwano ją potocznie Statutem Albertyńskim. Od 1861 r. Karta ta obowiązywała w całym Królestwie Italii aż do $1947 \mathrm{rr}^{20}$

Idea podziału władzy państwowej stała się odzwierciedleniem idei umowy społecznej. Jej początki przypadają na XVII w., a w XVIII w. zyskała sobie dużą popularność. Podstawowe założenie głosiło, iż dla zachowania wolności jednostki niezbędny jest rozdział władzy państwowej pomiędzy jej organy. Nigdzie zaś nie da się dokonać tak precyzyjnego i zarazem trwałego rozgraniczenia funkcji i kompetencji organów, jak właśnie w konstytucji. Tym przeświadczeniem należy również tłumaczyć słynny art. XVI francuskiej Deklaracji Praw Człowieka i Obywatela: „Każde społeczeństwo, w którym nie zapewniono gwarancji praw i nie ustanowiono podziału władz, jest pozbawione konstytucji”.

Ostatnią ważniejszą ideą (skądinąd najpóźniejszą - z lat 30. XIX w.), która przyczyniła się do pojawienia się konstytucji jako ustawy zasadniczej, był pozytywizm prawniczy. Za źródła prawa jego adherenci uznawali wyłącznie akty normatywne. Zakładał on możliwość derogacji norm prawnych wyłącznie przez inne normy prawne i opowiadał się za bezwzględnym posłuszeństwem wobec prawa stanowionego. Nietrudno się domyślić, że ideologia ta powstała w opozycji do idei prawa natury. A skoro tak, to wszelka podległość jednostki wobec państwa oraz wszelkie kompetencje jego organów winny zostać określone przez akt normatywny najwyższej rangi, ergo konstytucję.

\section{RUCHY KODYFIKACYJNE}

Trzeba pamiętać, że procesy konstytucyjne okresu Oświecenia (1772-1815) były też wspomagane przez ruchy kodyfikacyjne prawa sądowego. Również pod ich wpływem wydano wtedy ponad 60 ustaw zasadniczych, z których niewiele okazało się trwałych. Doszły one do skutku w bardzo różnych warunkach społeczno-ekonomicznych: od dominacji feudalnego typu gospodarowania i takich stosunków społecznych do ugruntowanych już stosunków wczesnokapitalistycznych. Powstały także w bardzo różnych okolicznościach politycznych, choć narodziny swe z reguły zawdzięczają gwałtownym wydarzeniom w rodzaju rewol-

${ }^{20}$ O politycznym tle ustanawiania pierwszych europejskich konstytucji oktrojowanych zob. L. Lacché, Granted Constitutions. The Theory of octroi and Constitutional Experiments in Europe and in the Aftermath of the French Revolution, "European Constitutional Law Review" 2013, Vol. 9(2), DOI: https://doi.org/10.1017/S1574019612001150, s. 285-314. 
ty, rewolucji czy zamachu stanu. Tak np. Konstytucja 3 Maja została uchwalona w trybie szczególnym - był to w istocie zamach stanu. Podobnie było ze szwedzką Regeringsformen przyjętą przez Riksdag w 1772 r. Konstytucje oświeceniowe miały też bardzo różny charakter. Jedne kodyfikowały reguły bliskie jeszcze monarchii stanowej, drugie próbowały zracjonalizować monarchię absolutną drogą ograniczonego włączenia reprezentacji społeczeństwa do procesu podejmowania decyzji państwowych, inne zaś poszukiwały nowych rozwiązań ustrojowych, odpowiadających istotnie zmienionym relacjom społeczno-politycznym. W początkach nowoczesnego konstytucjonalizmu nie było jeszcze utrwalonych wzorów, więc twórcy ustaw zasadniczych musieli działać metodą prób i błędów ${ }^{21}$.

Twórcy Konstytucji 3 Maja traktowali ją jako ustawę zasadniczą. Takie akty w sensie materialnym wydawano już wcześniej, jak np. Artykuły henrykowskie. Nie spełniały one jednak wymagań, jakie w Wieku Świateł stawiano każdej kodyfikacji, czyli jasności, systematyczności i zupełności. Poza tym nie były ustawami zasadniczymi w sensie formalnym, tj. mającymi wyższą moc prawną od wszelkich innych ustaw oraz uchwalanymi i zmienianymi w trybie trudniejszym niż te akty. Tymczasem takie przekonanie dotyczyło szeregu dawnych aktów ustrojowych, z tzw. prawami kardynalnymi na czele, które określały się jako „nigdy odmienić się niemogące"22. Z samej Konstytucji 3 Maja nie wynika wprost, że miała mieć wyższą moc prawną wobec ustaw. Wynika to z niej tylko pośrednio.

$$
\text { PIĘĆ ,FAL” }
$$

W moim przekonaniu można wyróżnić pięć „fal” uchwalania ustaw zasadniczych, zwłaszcza na kontynencie europejskim ${ }^{23}$.

Fala pierwsza to lata 1787-1831. Zostały wówczas uchwalone pierwsze konstytucje, m.in. amerykańska (1787), polska $(1791)^{24}$, francuska (1791), szwedzka

${ }^{21}$ H. Izdebski, op. cit., s. 5, 7-9.

22 Zob. ibidem, s. 5-6.

23 Zbliżoną periodyzację podał Adam Jamróz (Demokracja wspótczesna. Wprowadzenie, Białystok 1993, s. 152-154). Natomiast André Hauriou wymienił cztery duże etapy konstytucjonalizacji: a) amerykańska Deklaracja Niepodległości i francuska Deklaracja Praw Człowieka i Obywatela; b) konstytucje powstałe w efekcie rewolucji z lat 1830 i 1848; c) konstytucje uchwalone po 1918 r.; d) konstytucje uchwalone po 1945 r. Zob. H. Gangl, Der deutsche Weg zum Verfassungsstaat im 19. Jahrhundert. Eine Problemskizze, „Der Staat“ 1975, Nr. 1 (Beiheft 1), s. 30.

24 Interesujące, że uchwalenie Konstytucji 3 Maja spotkało się z pozytywnym oddźwiękiem ówczesnej prasy niemieckiej (m.in. „Berlinische Monatschrift”). Pozytywnie - choć cokolwiek zastanawiająco - ocenił ją także Edmund Burke, który w artykule pt. Apel od nowych do starych wigów (Appeal from the New to the Old Whigs) uznał ją za „zwykły postęp prowadzący do stałej doskonałości konstytucji brytyjskiej”. Zob. G.-C. von Unruh, Die polnische Konstitution vom 3. Mai 1791 im Rahmen der Verfassungsentwicklung der europäischen Staaten, „Der Staat“ 1974, Nr. 2, s. 204-205. 
(1809), hiszpańska $(1812)^{25}$, norweska $(1814)^{26}$, szwajcarska (1815), pierwsze niemieckie ustawy zasadnicze (było ich około 30) ${ }^{27}$, holenderska (1815) i belgijska $(1831)^{28}$.

Fala druga to konstytucje będące pokłosiem Wiosny Ludów. Chodzi tu zwłaszcza o pruską ustawę zasadniczą (1850) oraz austriackie ustawy konstytucyjne z lat $1848-1867$.

Fala trzecia to konstytucje uchwalane bezpośrednio po zakończeniu I wojny światowej, a więc: niemiecka (1919), fińska (1919), austriacka (1920), czechosłowacka (1920), polska (1921), estońska (1920), łotewska (1922), litewska (1922) ${ }^{29}$, rumuńska (1923), radziecka $(1918,1924)$ i inne. Przynajmniej kilka z nich to tzw. konstytucje profesorskie: Holgera Preussa (Niemcy), Kaarla Juho Stahlberga (Finlandia), Hansa Kelsena (Austria) i Edwarda Dubanowicza (Polska).

Fala czwarta to konstytucje, które doszły do skutku bezpośrednio po zakończeniu II wojny światowej. Trzeba tu wymienić zwłaszcza ustawę zasadniczą francuską (1946), włoską (1947), zachodnioniemiecką (1949) oraz ustawy

25 W Hiszpanii został wówczas uchwalony akt zwany konstytucją z Kadyksu (składający się z 384 artykułów), wzorowany na francuskiej ustawie zasadniczej z 1791 r. Król Ferdynand szybko tę konstytucję uchylił, gdyż solą w oku była dlań zasada suwerenności narodu i podziału władzy. Wprawdzie w 1820 r. został zmuszony do jej przywrócenia, niemniej trzy lata później znów ją uchylił i rządził do śmierci (1833) absolutnie. W świecie iberoamerykańskim akt ten jest darzony wielką rewerencją. Zob. L. Prakke, On the Rise and Decline of the Monarchical Principle: Constitutional Vicissitudes in Spain and Germany, "European Constitutional Law Review" 2010, Vol. 6(2), DOI: https://doi.org/10.1017/S1574019610200068, s. 276-277.

${ }_{26}$ Konstytucja Norwegii została uchwalona przez Konwencję z Eidsvoll, wybraną przez wszystkich dorosłych mężczyzn zebranych w kościołach. Ze 112 delegatów 59 rekrutowało się z wyższej kadry rządowej, 16 było zamożnymi przedsiębiorcami, a 37 - chłopami. Zob. G. Kousoulas, On Government: A Comparative Introduction, Belmont 1968, s. 57.

27 R. Dietrich, Einleitung über Probleme Verfassungsgeschichtlicher Forschung in unserer Zeit, „Der Staat“ 1975, Nr. 1 (Beiheft 1), s. 10.

28 Należą do nich też krótkotrwałe konstytucje francuskich państw satelickich: helwecka (1795), cyspadańska (1796), cyzalpińska (1797), liguryjska (1797), rzymska (1798) i neapolitańska (1799). Kilka lat później, po pokonaniu Prus, ustawy zasadnicze otrzymały państwa należące do Związku Reńskiego: Westfalia (1807), Bawaria (1808), Saksonia-Weimar (1809), Frankfurt (1810), Anhalt-Köthen (1810). Były to wszak „napoleońskie konstytucje pozorne”. Zob. K. Stern, Das Staatsrecht der Bundesrepublik Deutschland, Bd. 1, München 1984, s. 65; P. Unruh, Der Verfassungsbegriff des Grundgesetzes. Eine verfassungstheoretische Rekonstruktion, Tübingen 2002, s. 207. Samodzielne niemieckie ustawy zasadnicze mogły powstać dopiero po uwolnieniu od władztwa Napoleona.

29 Brak własnych tradycji ustrojowych spowodował, że ustawy zasadnicze Estonii i Łotwy były nader lakoniczne, siłą rzeczy pozostawiając poza regulacją konstytucyjną szereg istotnych zagadnień ustrojowych. Niewiele lepsza pod tym względem była konstytucja Litwy, która na dodatek grzeszyła niedopracowaną systematyką ogólną. Zob. P. Kierończyk, O specyfice pierwszych konstytucji państw baltyckich, „Studia Iuridica Toruniensia” 2013, t. 13, DOI: https://doi.org/10.12775/ SIT.2013.016, s. 44-45. 
zasadnicze krajów tzw. demokracji ludowej ${ }^{30}$. W państwach demokratycznych konstytucje były opracowywane $\mathrm{z}$ intencją remedium na niedostatki ustrojowe poprzednich ustaw konstytucyjnych, takich jak niestabilny system rządów, brak sądownictwa konstytucyjnego oraz niedostatki procedur ochrony wolności i praw obywatelskich. Te doświadczenia stały się punktem wyjścia dla tworzenia ustaw zasadniczych również tych krajów, które zerwały z autorytaryzmem, jak Grecja (1975), Portugalia (1976) i Hiszpania (1978).

Fala piąta to konstytucje, które zostały uchwalone w efekcie Jesieni Ludów, a więc po 1989 r. I znowu chodzi tu o kraje bloku wschodniego (1991-1998), czyli o tzw. nowe demokracje. Są to: Chorwacja, Litwa, Bułgaria, Rumunia, Macedonia, Słowenia (1991), Estonia, Czechy, Słowacja (1992), Rosja (1993), Ukraina (1996), Polska (1997) i Albania (1998).

Odnośnie do zachodniej hemisfery należy stwierdzić, że do 1945 r. właściwie wszystkie tamtejsze konstytucje - czyli Wenezueli, Argentyny i Chile (1811) oraz Meksyku i Brazylii (1824) - zdradzają wpływy ustawy zasadniczej USA. Z kolei po 1945 r. - uwzględniając także półkulę wschodnią - ów wpływ jest zauważalny w konstytucjach RFN, Japonii, Indii, Kanady i Hondurasu (1982), Salwadoru (1983), Liberii (1984), Gwatemali (1985) i Filipin (1987) ${ }^{31}$.

\section{BIBLIOGRAFIA}

Blaustein A.P., Our Most Important Export, [w:] Konstytucja Stanów Zjednoczonych Ameryki w perspektywie nauk historycznych i prawnych, red. J.L. Justyński, Torun 1988.

Dietrich R., Einleitung über Probleme Verfassungsgeschichtlicher Forschung in unserer Zeit, „Der Staat"“ 1975, Nr. 1 (Beiheft 1).

Esmein A., Prawo konstytucyjne, Warszawa 1921.

Gangl H., Der deutsche Weg zum Verfassungsstaat im 19. Jahrhundert. Eine Problemskizze, „Der Staat" 1975, Nr. 1 (Beiheft 1).

Grimm D., Verfassungsfunktion und Grundgesetzreform, „Archiv des öffentlichen Rechts“ 1972, Bd. 97(4).

Haskins G.L., The Legal Heritage of Plymouth Colony, [w:] American Law and the Constitutional Order. Historical Perspectives, eds. L.M. Friedman, H.N. Schreiber, Cambridge-London 1978.

Izdebski H., Konstytucja Trzeciego Maja wśród konstytucji swojego wieku, „Państwo i Prawo” 1991, z. 5.

„Jahrbuch des öffentlichen Rechts der Gegenwart“ 2000, Bd. 48.

Jamróz A., Demokracja wspótczesna. Wprowadzenie, Białystok 1993.

Kant I., Projekt wieczystego pokoju, Warszawa 1995.

30 Jak napisał Gerd Roellecke (Beobachtung der Verfassungstheorie, [w:] Verfassungstheorie, s. 58), jeśli poważnie potraktować art. 16 francuskiej Deklaracji Praw Człowieka i Obywatela, to te ustawy zasadnicze nie były w ogóle konstytucjami. Były to zaledwie ,pseudo- lub semikonstytucje”.

31 A.P. Blaustein, Our Most Important Export, [w:] Konstytucja Stanów Zjednoczonych Ameryki w perspektywie nauk historycznych i prawnych, red. J.L. Justyński, Toruń 1988, s. 160-164. 
Kierończyk P., O specyfice pierwszych konstytucji państw baltyckich, „Studia Iuridica Toruniensia” 2013, t. 13, DOI: https://doi.org/10.12775/SIT.2013.016.

Kousoulas G., On Government: A Comparative Introduction, Belmont 1968.

Lacché L., Granted Constitutions. The Theory of octroi and Constitutional Experiments in Europe and in the Aftermath of the French Revolution, "European Constitutional Law Review" 2013, Vol. 9(2), DOI: https://doi.org/10.1017/S1574019612001150.

Loewenstein K., Verfassungslehre, Tübingen 1969 (1957).

Loughlin M., What is Constitutionalisation?, [w:] The Paradox of Constitutionalism. Constituent Power and Constitutional Form, eds. M. Loughlin, N. Walker, Oxford 2007.

Maćkowska K., Normatywny wymiar amerykańskich wczesnych konstytucji stanowych, Lublin 2008.

McIlwain Ch.H., Constitutionalism Ancient and Modern, New York 1947.

Morey W.C., The Genesis of a Written Constitution, "Annals of the American Academy of Political and Social Science" 1891, No. 4.

Prakke L., On the Rise and Decline of the Monarchical Principle: Constitutional Vicissitudes in Spain and Germany, "European Constitutional Law Review" 2010, Vol. 6(2),

DOI: https://doi.org/10.1017/S1574019610200068.

Roellecke G., Beobachtung der Verfassungstheorie, [w:] Verfassungstheorie, Hrsg. O. Depenheuer, C. Grabenwarter, Tübingen 2010.

Roellecke G., Institutionelle Gewähr der Verfassung, [w:] Verfassungstheorie, Hrsg. O. Depenheuer, C. Grabenwarter, Tübingen 2010.

Schmitt C., Nauka o konstytucji, Warszawa 2013 (1928).

Stern K., Das Staatsrecht der Bundesrepublik Deutschland, Bd. 1, München 1984.

Stern K., Grundideen europäisch-amerikanischer Verfassungsstaatlichkeit, Berlin-New York 1984.

Unruh G.-C. von, Die polnische Konstitution vom 3. Mai 1791 im Rahmen der Verfassungsentwicklung der europäischen Staaten, „Der Staat“ 1974, Nr. 2.

Unruh P., Der Verfassungsbegriff des Grundgesetzes. Eine verfassungstheoretische Rekonstruktion, Tübingen 2002.

Wahl R., Der Konstitutionalismus als Bewegungsgeschichte, „Der Staat“” 2005, Nr. 4.

\section{SUMMARY}

The author starts his paper with some introductory remarks. He advances the thesis that the first constitutions have been passed by the end of the $18^{\text {th }}$ century, however, their originals could be found 150 years before. In addition, he presents the socio-economic background of the genesis of a constitution and demonstrates that a constitution was to petrify social progress won by the bourgeois revolution. There is also discussed the ideological background of the mentioned genesis, i.e. such mental currents as rationalism and liberalism as well as the idea of natural rights, popular sovereignty, social contract, distribution of power and legal positivism. Briefly mentioned is the influence of the codification movements of judicial law upon the constitutional processes of the age of Enlightenment, as well as the specification of five "waves" of passing constitutions in Europe.

Keywords: constitution; genesis; socio-economic background; ideological background

\section{STRESZCZENIE}

Artykuł rozpoczynają uwagi wstępne. Autor m.in. wskazuje, że pierwsze konstytucje zaczęto uchwalać pod koniec XVIII w., niemniej ich pierwowzory pojawiły się półtora stulecia wcześniej. Ponadto przedstawia tło społeczno-ekonomiczne genezy konstytucji oraz rozwija tezę, że konstytu- 
cja miała petryfikować osiągnięty w wyniku rewolucji burżuazyjnej postęp społeczny. Omówiono też tło ideologiczne, a konkretnie takie prądy ideowe, jak racjonalizm i liberalizm, a także ideę praw naturalnych, suwerenność ludu, umowę społeczną, podział władzy i pozytywizm prawniczy. Krótko wspomniano o wpływie ruchów kodyfikacyjnych prawa sądowego na procesy konstytucyjne okresu Oświecenia, a także wskazano pięć „fal” uchwalania ustaw zasadniczych na kontynencie europejskim.

Słowa kluczowe: konstytucja; geneza; tło społeczno-ekonomiczne; tło ideologiczne 